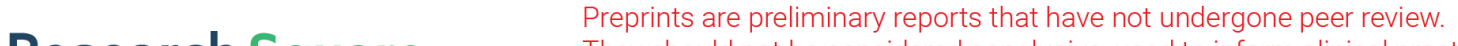 They should not be considered conclusive, used to inform clinical practice, or referenced by the media as validated information. \\ Does the regulatory effect of vitamin $\mathrm{D}$ allow to reduce the cisplatin dose in T24 bladder cancer cell line?
}

\section{Özge Özgen ( $\square$ 00ozge01@gmail.com )}

Istanbul University, Aziz Sancar Institute of Experimental Medicine, Department of Molecular Medicine https://orcid.org/0000-0002-1859-3962

\section{Güneş Özen Eroğlu}

Istanbul University, Aziz Sancar Institute of Experimental Medicine, Department of Molecular Medicine

Nilgün Akdeniz

Istanbul Universitesi, Aziz Sancar Institute of Experimental Medicine, Department of Immunology

Ceylan Hepokur

Sivas Cumhuriyet Universitesi

\section{Serap Kuruca}

Istanbul University Istanbul Faculty of Medicine: Istanbul Universitesi Istanbul Tip Fakultesi

İlhan Yaylım

Istanbul University, Aziz Sancar Institute of Experimental Medicine, Department of Molecular Medicine

\section{Research Article}

Keywords: Bladder cancer, T24 cell line, Calcitriol, Cisplatin, Vitamin D, P-gp, Apoptosis

Posted Date: March 2nd, 2022

DOI: https://doi.org/10.21203/rs.3.rs-1389662/v1

License: (c) (i) This work is licensed under a Creative Commons Attribution 4.0 International License.

Read Full License 


\title{
Does the regulatory effect of vitamin D allow to reduce the cisplatin dose in $T 24$ bladder cancer
} cell line?

Özge Özgen ${ }^{1}$, Güneş Özen Eroğlu${ }^{1}$, Nilgün Akdeniz², Ceylan Hepokur ${ }^{3}$, Serap Kuruca ${ }^{4}$, İlhan Yaylım

${ }^{1}$ Istanbul University, Aziz Sancar Institute of Experimental Medicine, Department of Molecular Medicine, Istanbul, Turkey

${ }^{2}$ Istanbul University, Aziz Sancar Institute of Experimental Medicine, Department of Immunology, Istanbul, Turkey

${ }^{3}$ Cumhuriyet University, Faculty of Pharmacy, Department of Medical Biochemistry, Sivas, Turkey

${ }^{4}$ Istanbul University, Istanbul Faculty of Medicine, Department of Physiology, Istanbul, Turkey

\section{Corresponding Author: Özge Özgen}

Address: Istanbul University, Aziz Sancar Institute of Experimental Medicine, Department of Molecular Medicine. Fatih-Capa/Istanbul

E-Mail: drozgozgen@gmail.com

\begin{abstract}
1,25(OH)2D3 (Calcitriol, active form of Vitamin D), which is a broad regulatory molecule, plays a role in changing the efficacy of chemotherapeutic drugs. In bladder cancer, effectiveness of the treatment and reducing the resistance to chemotherapeutics such as cisplatin are of great importance. Cisplatin usage is one of a current standard chemotherapy regimen for bladder cancer. In our study T24, ECV-304 and HUVEC cell lines were treated with calcitriol and cisplatin individually and with combination. MTT assays were used for optimal dose determination. It was aimed to determine the possible potential of the combined use of cisplatin with calcitriol. Determined doses and combination treatments of calcitriol and cisplatin on all cell lines were evaluated for cytotoxicity, apoptosis and drug resistance. Also calcitriol and cisplatin interaction with p53 protein was assessed by molecular docking analysis. Datas showed that combination treatment increased the anti-proliferative efficacy compared to cisplatin alone ( $\mathrm{p}=0.0108)$ in T24 cells. Also it reduced the cytotoxicity in the HUVEC compared to cisplatin alone $(\mathrm{p}<0.0001)$. Combination treatment achieved slightly higher apoptosis rate in T24 cells than treatment of cisplatin alone ( $\mathrm{p}=0.0005)$. It was determined that the rate of apoptosis and P-gp levels did not change significantly in the ECV-304 cells. However it decreased in HUVEC healthy control cell line ( $\mathrm{p}=0.0082)$. P-gp ratios were increased in HUVEC ( $p<0.0001)$ and decreased in T24 cells $(74.47 \% \mathrm{p}<0.0001)$ compare to control. The data obtained in this study show that the combination of calcitriol and cisplatin allows the use of cisplatin at lower doses.
\end{abstract}

Key Words: Bladder cancer, T24 cell line, Calcitriol, Cisplatin, Vitamin D, P-gp, Apoptosis

\section{Introduction}

Variations in multiple cancer rates, in survival rates and variability in cancer development make it difficult to determine the incidence rates in bladder cancer. Bladder cancer is the 10th type of cancer in worldwide. Its incidence in men is three times higher than in women. It is known that environmental, demographic and genetic factors are effective in the development of bladder cancer. Although there are various difficulties in determining the rates of effect on disease development, it is known that the incidence of bladder cancer development is high in industrial societies (1).

During the chemotherapeutic treatment of bladder cancer, agents such as valrubicin, gemstabin, docataxel, cabazitaxel, mitomycin C, cisplatin and their combinations are used (2). Various side effects associated with the 
use of these chemotherapeutics are undesirable systemic effects. Developed optimal treatment strategies may provide an advantage in reducing the side effects associated with chemotherapeutic usage.

In addition to chemotherapeutic treatment, calcitriol $(1,25$-dihydroxyvitamin D3 $(1,25 \mathrm{D} 3))$ the active form of vitamin D, may also be an option for the development of more effective treatment for bladder cancer (3-4). Calcitriol have several beneficial effects about the regulation of cell metabolism including anti-proliferation, proapoptotic effects, anti-cell migration and anti-angiogenic activities (5).

The pathogenesis of bladder cancer emerges with mutations in somatic cells and failure of protooncogenes and tumor suppressor genes to maintain their normal functions (6). P53 is one of the most commonly mutated tumor suppressor gene in cancer. P53 loss is associated with a variety of undesirable phenotypic properties, including apoptotic signaling error and lack of cell cycle checkpoint regulation (7). Mutations in p53 are associated with cisplatin resistance in many cancer types and poor prognosis in bladder cancer (8-9).

Cisplatin damages the tumor through apoptosis by connecting with DNA and transduction pathways (calcium signaling, receptor signaling, activation of mitochondrial pathways, etc.). However, the most important problems in the use of cisplatin are the high systemic side effects experienced by the patients and the development of drug resistance and the decrease in the effectiveness of the treatment (10).

Therefore, in our study, we aimed to evaluate the possible cytotoxic, apoptotic and drug resistance effects of combination therapy on bladder cancer cell lines in vitro.

\section{Materials and Methods}

\section{Chemicals and reagents}

Stock solution was prepared by dissolving calcitriol (Sigma) in ethanol at a concentration of $10000 \mathrm{nM}$. Cisplatin (Kocak Farma) is available in commercially purchased form as $25 \mathrm{mg} / 50 \mathrm{~mL}$. Dilutions of all concentrations applied in the experiments were prepared using cell culture medium.

\section{Cell Culture}

The T24 human bladder cancer cell line, ECV-304 cancer cell line and HUVEC endothelial cell line from ATCC(American Type Culture Collection) for the control cell line were cultured for our studies. Cell culture was performed using Dulbecco's Modified Eagle's Medium (DMEM)-low glucose (Sigma Aldrich) in the presence of $10 \%$ fetal bovine serum (Biosera), $1 \%$ penicillin $(100 \mathrm{U} / \mathrm{mL}) /$ streptomycin $(100 \mu \mathrm{g} / \mathrm{mL})(\mathrm{Gibco})$ in a humidified atmosphere containing $5 \% \mathrm{CO} 2$.

\section{MTT Assay}

The 3-(4,5-dimethylthiazol-2-yl)-2,5-diphenyltetrazolium bromide (MTT) cell viability assay was performed as previously described. Cells were seeded at a density of $5 \times 10^{3}$ cells per well of a 96- well plate in $100 \mu \mathrm{L}$ of culture medium and were incubated for $24 \mathrm{~h}$ to ensure the adherence. The cells were treated for $24 \mathrm{~h}, 48 \mathrm{~h}, 72 \mathrm{~h}$ with each different concentrations of calcitriol (25-1000 nM), and cisplatin (16.6-166 $\mu \mathrm{M})$. Combination treatments of the calcitriol $(500 \mathrm{nM})$ and cisplatin $(16.6 \mu \mathrm{M})$ were also performed at the same time periods. In brief, at the end of the treatment period, $10 \mu \mathrm{L}$ of MTT solution $(5 \mathrm{mg} / \mathrm{mL}$ in PBS) was added to each well. Following incubation for $4 \mathrm{~h}$ at $37{ }^{\circ} \mathrm{C}$ to allow the conversion of MTT to formazan crystals, $100 \mu \mathrm{L}$ of dimethyl sulfoxide (DMSO) was added and the formazan crystals formed were dissolved. The OD was measured at $570 \mathrm{~nm}$ using ELISA microplate reader (Rayto RT-2100C, AB Medical). Viability of treated cells was calculated in reference to the untreated control cells using the following formula: viability $(\%)=(100 x($ sample Abs $) /($ control Abs $))$, where Abs is the absorbance value at $570 \mathrm{~nm}(11)$.

\section{Analysis of Apoptosis}

The cells were incubated for $24 \mathrm{~h}$ with calcitriol, cisplatin and combination treatments in 6-well plates. At the end of the period, the cells were removed with trypsin, harvested, resuspended in cold PBS ( to a concentration of $1 \times 10^{6}$ cells $/ \mathrm{mL}$ ) after centrifugation. After washing 2 times with PBS, Annexin V and PI dye staining process started. Sample preparations prior to flow cytometric analysis were performed according to the manufacturer's instructions (EXBIO Apo FlowEx FITC). The analysis of flow cytometry was carried out using Novocyte (Acea Biosciences, Inc., USA). 


\section{P-glycoprotein Analysis}

P-glycoprotein is an important drug transporter that has been identified in various types of cancer and is well known to be associated with chemotherapy resistance.

Cells treated with calcitriol, cisplatin and combination were trypsinized, harvested and centrifuged after 24 hours. Cell pellets obtained by centrifugation were resuspended with cold PBS. Washing with PBS was repeated 2 times. Cells were prepared for staining of P-gp protein. For flow cytometric examination of P-gp expression, MDR1 (UIC2) was used conjugated to phycoerythrin (MDR-1 PE, Santa Cruz). Cells to be analyzed were adjusted to $1 \times 10^{6}$ cells $/ \mathrm{mL}$. Staining and analysis of P-gp protein was performed according to the manufacturer's instructions.

\section{Docking Analysis}

In the molecular docking study, the activities of calcitriol and cisplatin molecules against p53 protein were investigated. Hex 8.0.0 (a well-known highly advanced protein and ligand docking tool) was used for protein and drug interaction. Docking data was calculated using the HEX 8.0.0 program for this protein docking study.

The structure of p53 was retrieved from protein data bank (PDB) archive as PDB ID: 2MWY.

\section{Statistical Evaluation}

MTT, P-gp and Annexin V-PI values were statistically evaluated with the unpaired Student-T test using GraphPad Prism 5.04 Software. HEX 8.0.0 program was used in the evaluation of molecular docking datas. Analysis of apoptosis and P-gp expression by flow cytometry was performed with NovoExpress 1.3.0 software.

\section{Results}

\section{Optimal Cytotoxic Dosage Determination By MTT Assay}

Cytotoxic evaluation for determination of optimum dose for calcitriol and cisplatin in T24, ECV-304, HUVEC cell lines was performed by MTT test. The cytotoxic effect of $25 \mathrm{nM}-1000 \mathrm{nM}$ doses for calcitriol, 16.6 $\mu \mathrm{M}-166 \mu \mathrm{M}$ doses for cisplatin was evaluated in all cells at $24 \mathrm{~h}, 48 \mathrm{~h}, 72 \mathrm{~h}$. As a result of MTT, two different antiproliferative doses $(25 \mathrm{nM}$ and $500 \mathrm{nM})$ were determined for calcitriol. The optimum dose of cisplatin $7.6 \mu \mathrm{g} / \mathrm{ml}$ for $100 \% \mathrm{TDC}(25.23 \mu \mathrm{M})$ was reported in the literature (12).

Fig 1 MTT assay results for calcitriol treatment in T24 (A), ECV-304 (B), HUVEC (C) cell lines with doses between $25 \mathrm{nM}$ to $1000 \mathrm{nM}$ for $24 \mathrm{~h}, 48 \mathrm{~h}$ and $72 \mathrm{~h}$. Cisplatin treatment in T24 (D), ECV-304 (E), HUVEC (F) cell lines with doses between $16.6 \mu \mathrm{M}$ to $166 \mu \mathrm{M}$ for $24 \mathrm{~h}, 48 \mathrm{~h}$ and $72 \mathrm{~h}$. Cells treated with cisplatin after $24 \mathrm{~h}$ cell cultivation. (G); Comparison of MTT results. Control cells (non treated), $500 \mathrm{nM}$ calcitriol, $16.6 \mu \mathrm{M}$ cisplatin and $500 \mathrm{nM}$ calcitriol $+16.6 \mu \mathrm{M}$ cisplatin for combination treatment was evaluated for $24 \mathrm{~h}$. Triplicated applications were done for all samples. Data are mean $\pm \operatorname{SEM}(n=3),\left({ }^{* * *} \mathrm{p}<0.001,{ }^{* *} \mathrm{p}<0.01,{ }^{*} \mathrm{p}<0.05\right.$, ns: non significant).

The lower dose of cisplatin ( $16.6 \mu \mathrm{M} ; 66 \%$ TDC) was evaluated by MTT and showed cytotoxic activity. As a result of MTT experiments, when all three cell lines were evaluated for calcitriol, $500 \mathrm{nM}$ dose was found to be optimum for combination treatment for $24 \mathrm{~h}$. In terms of cytotoxicity, the results revealed that calcitriol has a biphasic effect and a dose-dependent selective effect. According to the results, the combination treatment was maintained with $500 \mathrm{nM}$ for calcitriol with $16.6 \mu \mathrm{M}$ for cisplatin ( Fig. 1).

\section{Apoptosis and P-gp Expression Results}

Apoptosis which was applied with Annexin V/PI staining, evaluated for 500nM calcitriol, $16.6 \mu \mathrm{M}$ cisplatin, and combination treatment (500nM calcitriol $+16.6 \mu \mathrm{M}$ cisplatin) for $24 \mathrm{~h}$. According to our results, combination treatment achieved a higher apoptosis rate in T24 cell line than treatment of cisplatin alone $(\mathrm{p}=0.0005)$. It was determined that the rate of apoptosis did not change significantly in the ECV-304 cell line. It was observed that the rate of apoptosis decreased in HUVEC healthy control cell line ( $\mathrm{p}=0.0082)$ (Fig. 2). 
Examination of P-gp expression level evaluated for 500nM calcitriol, $16.6 \mu \mathrm{M}$ cisplatin, and combination treatment $(500 \mathrm{nM}$ calcitriol $+16.6 \mu \mathrm{M}$ cisplatin) for $24 \mathrm{~h}$. We found that the P-gp expression level of the combination treatment in the T24 cell line decreased by $\mathrm{p}<0.0001$ compared to the control and $\mathrm{p}<0.0001$ compared to the treatment of only cisplatin and only calcitriol (Fig. 3).

In the HUVEC cell line, the expression rate of P-gp increased with calcitriol treatment compared to the control $\mathrm{p}<0,0001$, while it decreased significantly with cisplatin treatment compared to the control $(\mathrm{p}=0.0005)$. P-gp expression levels in HUVEC cells, increased in combination treatment compared to control $\mathrm{p}<0.0001$. In addition, no significant changes were observed in terms of P-gp expression rates in the ECV-304 cell line. When the cisplatin treatment was evaluated statistically compared to the combination treatment in the ECV-304 cell line, the significance value was $\mathrm{p}=0,0616$ (Table 1, Fig.3).

Fig 2 Annexin V/PI staining represented images for T24 (A), ECV-304 (B) and HUVEC (C) cell lines for $24 \mathrm{~h}$. Control cells (non treated), $500 \mathrm{nM}$ calcitriol, $16.6 \mu \mathrm{M}$ cisplatin and $500 \mathrm{nM}$ calcitriol $+16.6 \mu \mathrm{M}$ cisplatin for combination treatment was evaluated. (D) Total apoptosis results for T24, ECV-304 and HUVEC. Triplicated applications were done for all samples. Data are mean $\pm \operatorname{SEM}(n=3),\left({ }^{* * *} \mathrm{p}<0.001,{ }^{*} \mathrm{p}<0.01,{ }^{*} \mathrm{p}<0.05\right.$, ns: non significant).

Fig 3 Represented images of P-gp exspression for T24 (A), ECV-304 (B) and HUVEC (C) cell lines for 24h. (D) P-gp results evaluation of control cells (non treated), calcitriol $(500 \mathrm{nM})$, cisplatin $(16.6 \mu \mathrm{M})$ and combination treatment (Calcitriol 500nM+ cisplatin $16.6 \mu \mathrm{M}$ ) for each three cell line. Triplicated applications were done for all samples. Data are mean $\pm \operatorname{SEM}(\mathrm{n}=3),\left({ }^{* * *} \mathrm{p}<0.001,{ }^{*} \mathrm{p}<0.01,{ }^{*} \mathrm{p}<0.05\right.$, ns: non significant $)$.

Table 1 Percentage ratios of MFI (Mean Fluorescence Intensity) obtained from flow cytometric analysis of P-gp expressions levels in T24, ECV-304 and HUVEC cells.

\begin{tabular}{|c|c|c|c|c|}
\hline Cell lines & Control & $\begin{array}{l}\text { Calcitriol } \\
(500 n M)\end{array}$ & Cisplatin $(16.6 \mu M)$ & $\begin{array}{l}\text { Calcitriol+ Cisplatin } \\
(500 n M+16.6 \mu M)\end{array}$ \\
\hline$T 24$ & 74.47 & 79.22 & 80.65 & $68.33 \Downarrow$ \\
\hline$E C V-304$ & 97.64 & 99.18 & 98.05 & 97.47 \\
\hline HUVEC & 87.08 & 92.50 & 86.09 & 92.16 \\
\hline
\end{tabular}

Data are mean $\pm \operatorname{SEM}(n=3)$. The difference between the treatments was analyzed by unpaired student's $t$ test.

\section{Docking Analysis}

According to docking analysis, calcitriol has higher binding energy with p53 molecule compared to cisplatin. It was evaluated simulatively with DNA Docking method in order to form the basis for future research.

Fig 4 Calcitriol-p53 and cisplatin-p53 interaction structures via to Docking Analysis.

Table 2 Docking analysis results showing the binding energies of calcitriol and cisplatin molecules in their interaction with p53 protein.

\begin{tabular}{|c|c|c|c|}
\hline & $E_{\text {total }}$ & $\boldsymbol{E}_{\text {shape }}$ & $\boldsymbol{E}_{\text {force }}$ \\
\hline Calcitriol & -282.10 & -282.10 & 0.00 \\
\hline Cisplatin & -135.16 & -135.16 & 0.00 \\
\hline
\end{tabular}

Docking data was calculated using the HEX 8.0.0 program for this protein docking study. 


\section{Discussion}

Cisplatin is a key ingredient for chemotherapeutic therapy in bladder cancer as part of drug combinations with methotrexate, vinblastine, adriamycin and cisplatin (MVAC) or gemcitabine, cisplatin (Gem-Cis) used to treat urethelial cell carcinomas (13). It is known that side effects can be occur as a result of chemotherapeutic drug usage. Reducing systemic side effects is extremely important in the success of bladder cancer treatment. In our study, the combined use of calcitriol molecule, which has high regulatory functions, with cisplatin was evaluated in terms of anti-proliferative, apoptotic properties and drug resistance in bladder cancer cell lines.

One of the cell lines we evaluated, the ECV-304 cell line, was identified as a bladder cancer-associated cell line in the past years. However, ECV-304 is thought to be transformed from the HUVEC cell line in the literature $(14,15)$. In addition, there is also a study showing the genetic identification of ECV-304 with the bladder cancer cell line T24/83 (16). In our study, we determined different values in cytotoxic, apoptotic and P-gp expression results of T24, ECV-304 and HUVEC cell lines for cisplatin and calcitriol. In this way, three different cell lines were compared with each other.

In our experiments, we adjusted the optimum dose of cisplatin and calcitriol to remain below the $100 \%$ TDC (Test Drug Concentration) level. A level of $100 \%$ TDC is the approximate level of plasma peak concentrations of the chemotherapeutics (12). Because exceeding 100\% TDC doses could come out systemic side effects when it comes to use in advanced clinical applications.

The $100 \%$ TDC dose of cisplatin in the literature was $(25.23 \mu \mathrm{M})(12)$. Therefore, we chose the ratio below the $100 \%$ TDC dose and $66 \%$ TDC $(16.6 \mu \mathrm{M})$ as the combination dose for cisplatin in our experiments. According to the literature, the IC50 dose for calcitriol in T24 bladder cancer cells was $40 \mu \mathrm{M}$ (17). Based on our MTT data on calcitriol, we benefited from its anti-proliferative properties at much lower dose levels (25nM-500nM) of calcitriol. We have determined that calcitriol has a biphasic effect at the cellular level. Calcitriol induced dose-dependent variable responses (Fig. 1). According to our basic approach, could we use the effect of calcitriol to reduce the dose of cisplatin or achieve the same effectiveness at a lower dose? As a preclinical data, it seems that yes we can.

There are studies in squamous cell carcinoma and pancreatic models that support our study of the use of calcitriol in combination with cisplatin. These studies provide preclinical data indicating that the combination of these two molecules enhances apoptosis and anti-tumoral response $(18,19,20)$. In another study, it was done with the doses between 0.8 and $10 \mu \mathrm{M}$ for calcitriol in $\mathrm{T} 24$ and $253 \mathrm{j}$ cell lines observed that proliferation was strongly inhibited. They mention that normal and neoplastic bladder tissue and cell lines express the Vitamin D receptor. Control groups and cell lines treated with calcitriol showed different responses in terms of apoptotic association. The results of this study gave data that calcitriol may be associated with bladder cancer $(17,18)$. However, studies on calcitriol and bladder cancer are limited.

Calcitriol has extensive regulatory effects. It changes the antitumoral activities of chemotherapeutic agents such as cisplatin by several mechanisms $(8,21)$. There are various publications showing that calcitriol can support cisplatin-based chemotherapy and have an anti-tumor effect in different types of cancer $(22,23,24)$.

The P-gp molecule is associated with drug resistance in the cell. In our study, we wanted to evaluate the P-gp expression that may be caused by calcitriol and cisplatin. There are various publications in the literature about the interaction of cisplatin and P-gp with each other. Tumors from patients treated with MVAC have been found to express higher levels of P-gp compared to untreated patients (25-26). However, most studies of P-gp expression in urethral carcinoma cells (UCC) show that it is not associated with cisplatin-based chemotherapy response (27, 28, 29). A recent large study at UCC suggests that increased P-gp expression is associated with a poor response to MVAC, and this effect is also thought to be due to cisplatin $(30,31,32)$. According to the in vitro studies producing doxorubicin-resistant UCC cells expressing high P-gp indicate that there is no increase in cisplatin resistance (28, $33,34,35)$. The role of P-gp in terms of overall clinical response and therapeutic function remains controversial. In addition, our datas make an additional contribution to these studies about P-gP. According to our data, the increase in P-gp expression level was consistent with apoptosis levels and gave significant results. The combination treatment caused a decrease in P-gp in T24 bladder cancer cells and an increase in P-gp in HUVEC healthy cell line. It also advantageously changed the apoptosis levels (Fig. 2, Fig. 3 and Table 1). With the increase of P-gp, a slight decrease in the apoptosis rate was detected in the HUVEC healthy cell line. These datas gave us 
possible clues that calcitriol may help to reduce the dose in the use of cisplatin, which has many side effects, and may contribute to the survival of healthy cells.

It is also shown in the literature that the T24 cell line has p53 mutation (36). Although we could not experimentally demonstrate the effectiveness of calcitriol and cisplatin against p53 protein, we wanted to evaluate it simulatively with DNA Docking method in order to form the basis for future research. At this point, it was started with the idea that p53 is one of the main targets of cisplatin and that changes in p53 may play a role in the response to chemotherapy. Sarkis et al. showed that p53 damage is a predictor of MVAC treatment success and survival ratios in patients with invasive bladder cancer (37). The p53 status is helpful in determining the response to chemotherapy or surgical procedures. Conversely, in the study of Cote et al., they found that the local and regional TCC patient group with abnormal p53 expression benefited from cisplatin-based adjuvant chemotherapy $(38,39,40)$. According to the datas we have reached, it has been determined that calcitriol has a higher rate of interaction against the p53 protein than cisplatin (Table 2, Fig. 4).

Our study reveals that calcitriol increases the effectiveness of cisplatin in bladder cancer cells preclinically. It also provides data that can be considered in the development of viable pharmacokinetic models. Considering the side effects of cisplatin, revealing the data to be obtained from studies on combination treatments with important regulatory molecules such as vitamin D may enable to increase the survival and life quality of bladder cancer patients.

\section{References}

1- Sung H., Ferlay J., Siegel R.L., Laversanne M., Soerjomataram I., Jemal A., Bray F. (2021). Global Cancer Statistics, GLOBOCAN Estimates of Incidence and Mortality Worldwide for 36 Cancers in 185 Countries. A cancer Journal for Clinicals, 71(3); 209-249 https://doi.org/10.3322/caac.21660

2-Urolojik Onkoloji Bülteni. Bladder Cancer 2018; 2(1);11-19 ISSN 2564-6699 https://www.uroturk.org.tr/urolojiData/Books/587/tud-urolojik-onkoloji-bulteni-mesane-kanseri-mart-2018-cilt2-sayi-1.pdf

3- Trump D.L.(2018). Calcitriol and cancer therapy: A missed opportunity. Bone Reports, 9; 110-119 doi: 10.1016/j.bonr.2018.06.002

4- Studzinski G.P., Gocek E., Danilenko M. (2011). Vitamin D, Vitamin D Effects on Differentiation And Cell Cycle (3nd edition). Elsevier; 84; page:1625-1656

5- Genç, A., Sevim, D.G., Özen, A.T., Yılmaz, G., D.(2015). The Area of Usage of the Vitamin D in Different Diseases and Unknown Benefits. Ankara Üniversitesi Tıp Fakültesi Mecmuas1. 68(2). DOI:10.1501/Tipfak_000000890.

6- Altaylı, E., Güneş, S. (2011). Mesane Kanseri Gelişiminde Moleküler Mekanizmaların Rolü. Turkiye Klinikleri Journal of Medical Science,31(1):191-205. doi: 10.5336/medsci.2009-13192

7- Slaton JW, Benedict WF, Dinney CP (2001). P53 in bladder cancer: mechanism of action, prognostic value, and target for therapy. Urology, 57(5):852-9. doi: 10.1016/s0090-4295(01)00968-2.

8- Ma Y., Yu W.D., Trump D.L. ve Johnson C.S.(2010). 1,25D3 Enhances Antitumor Activity of Gemcitabine and Cisplatin in Human Bladder Cancer Models; Cancer, 116(13): 3294-3303. doi: 10.1002/cncr.25059

9- Branch P, Masson M, Aquilina G, Bignami M, Karran P.(2000) Spontaneous development of drug resistance: mismatch repair and p53 defects in resistance to cisplatin in human tumor cells. Oncogene. 29;19(28):3138-45. doi: 10.1038/sj.onc.1203668.

10- Florea A.M., Büsselberg D.(2011). Cisplatin as an Anti-Tumor Drug: Cellular Mechanisms of Activity, Drug Resistance and Induced Side Effect. Cancers. 3; 1351-1371 doi:10.3390/cancers3011351

11- Mossman T. (1983). Rapid colorimetric assay for cellular growth and survival: application to proliferation and cytotoxicity assays. J Immunol Methods. 16;65(1-2):55-63. doi: 10.1016/0022-1759(83)90303-4. 
12 -Oral A.Y., Oral B.H., Sarımahmut M., Cevatemre B., Özkaya G., Korkmaz Ş. ,Ulukaya E. (2017) Combination of esomeprazole with chemotherapeutics results in more pronounced cytotoxic effect via apoptosis on A549 nonsmall-cell lung cancer cell line. Turk J Biol 41: 231-241 (C) TÜBİTAK doi:10.3906/biy-1606-46)

13- Flaig T.W., Spiess P.E., Agarwal N., Bangs R., Boorjian S.A., Buyyounouski M.K, Chang S., et al.(2020) Bladder Cancer, Version 3.2020, NCCN Clinical Practice Guidelines in Oncology. JNCCN, 18(3). DOI: https://doi.org/10.6004/jnccn.2020.0011

14- Zuiverloon T.C.M, Jonga F.C, Costelloc J.C., Theodorescu D. (2018). Systematic Review: Characteristics and Preclinical Uses of Bladder Cancer Cell Line. Bladder Cancer, 4; 169-183 DOI 10.3233/BLC-180167

15- Konstantakou E.G., Voutsinas G.E., Karkoulis P.K., Aravantinos G., Margaritis L.H., Stravopodis D.J. (2009). Human bladder cancer cells undergo cisplatin-induced apoptosis that is associated with p53 dependent and p53independent responses. Int. J. Oncol, 35(2), 401-416 PMID: 19578756

16- Brown J., Reading S. J., Jones S., Fitchett C.J., Howl J., Martin A., et al.(2000). Critical Evaluation of ECV304 as a Human Endothelial Cell Model Defined by Genetic Analysis and Functional Responses: A Comparison with the Human Bladder Cancer Derived Epithelial Cell Line T24/83. Laboratory Investigation 80 (1);37-45 doi: 10.1038/labinvest.3780006

17- Konety B.R., Lavelle J.P., P1rtskalaıshvılı G., Dihır R., Meyers S.A., Neguen T.S.T., et al. (2001). Effects of Vitamin D on Transitional Cell Carsinoma of The Bladder In Vitro and In Vivo. J Urol. 165(1):253-8. doi: 10.1097/00005392-200101000-00074.

18- Bunch B.L., Ma Y., Attwood K., Amable L., Luo W., Morrison C.,Khurshid A. Guru K.A., et al. (2019). Vitamin D3 enhances the response to cisplatin in bladder cancer through VDR and TAp73 signaling crosstalk. Cancer Med, 8(5):2449-2461. doi: 10.1002/cam4.2119. Epub 2019 Apr 10.

19- Ma Y, Yu W-D, Hershberger PA, Flynn G.; Rui-Xian Kong R.X., Trump D.L., Johnson S.C., (2008). 1alpha,25-Dihydroxyvitamin D3 potentiates cisplatin antitumor activity by p73 induction in a squamous cell carcinoma model. Mol Cancer Ther., 7:3047-3055. https://doi.org/10.1158/1535-7163.MCT-08-0243.

20- Yu W-D, Ma Y, Flynn G, Muindi J.R., Kong R-X, Trump D.L., Johnson C.S., (2010). Calcitriol enhances gemcitabine antitumor activity in vitro and in vivo by promoting apoptosis in a human pancreatic carcinoma model system. Cell Cycle. 9;3094-3101. https://doi.org/10.4161/cc.9.15.12381.

21- Deeb K.K., Trump D.L., Johnson C.S. (2007). Vitamin D signalling pathways in cancer: potential for anticancer therapeutics. Nat Rev Cancer, 7; 684- 700. DOI: 10.1038/nrc2196

22- Gan X , Chen B., Shen Z. , Liu Y., Li H. , Xie X. , Xu X. et al.(2014). High GPX1 expression promotes esophageal squamous cell carcinoma invasion, migration, proliferation and cisplatin-resistance but can be reduced by vitamin D. Int J Clin Exp Med. 7(9): 2530-2540. PMID: 25356106

23- Zeng X., Zhang L., Jia S., Lin T, Liu G., Yue J., Huang X. (2021). Effects of Circulating 25(OH)D Status in Advanced Colorectal Cancer Patients Undergoing Chemotherapy: A Systematic Review. Anticancer Research 41 (12); 5903-5912; DOI: https://doi.org/10.21873/anticanres.15409

24- Mendoza M.S., Quiroz J.G. , Díaz L., Becerra R.G..(2021) Combinations of Calcitriol with Anticancer Treatments for Breast Cancer: An Update. Int. J. Mol. Sci. 22(23); 12741; https://doi.org/10.3390/ijms222312741

25- Petrylak D.P., Scher H.I., Reuter V., O’brien J.P., Cordon-Cardo C. (1994). Pglycoprotein expression in primary and metastatic transitional cell carcinoma of the bladder. Ann Oncol. 5(9):835-40. doi: 10.1093/oxfordjournals.annonc.a059013.

26- Tada Y., Wada M., Migita T., Nagayama J., Hinoshita E., Mochida Y. et al.(2002). Increased expression of multidrug resistance associated proteins in bladder cancer during clinical course and drug resistance to doxorubicin. Int. J. Cancer 98(4), 630-635.

27- Takara K, Sakaeda T, Yagami T., Kobayashi H., Ohmoto N., Horinouchi M., et al. (2002). Cytotoxic effects of 27 anticancer drugs in HeLa and MDR1-overexpressing derivative cell lines. Biol Pharm Bull. 25(6):771-8. doi: $10.1248 / \mathrm{bpb} .25 .771$. 
28- Sandlow J., Cohen M.B., Robinson R.A., Dreicer R., Williams R.D. 1994. DNA ploidy and P-glycoprotein expression as predictive factors of response to neoadjuvant chemotherapy for invasive bladder cancer. Urology 43(6):787-91. doi: 10.1016/0090-4295(94)90136-8.

29- Siu L.L., Banerjee D., Khurana R.J., Pan X., Pflueger R., Tannocket I.F. et al.(1998). The prognostic role of p53, metallothionein, P-glycoprotein, and MIB-1 in muscleinvasive urothelial transitional cell carcinoma. Clin. Cancer Res. 4(3), 559-565. PMID: 9533522

30- Shen F, Chu S, Bence A.K., Bailey B., Xue X., Erickson P.A. et al. (2008). Quantitation of doxorubicin uptake, efflux, and modulation of multidrug resistance (MDR) in MDR human cancer cells. J. Pharmacol. Exp. Ther. 324(1), 95-102

31- Bruggemann E.P., Currier S.J., Gottesman M.M., Pastan I. (1992). Characterization of the azidopine and vinblastine binding site of P-glycoprotein. J. Biol. Chem. 267(29), 21020-21026 PMID: 1356986

32- De Graaf D, Sharma R.C., Mechetner E.B., Schimke R.T., Roninson I.B. (1996). P-glycoprotein confers methotrexate resistance in 3T6 cells with deficient carrier-mediated methotrexate uptake. Proc. Natl Acad. Sci. 1996; 93(3), 1238-1242 doi: 10.1073/pnas.93.3.1238

33- Drayton R.M., Catto JW. (2012) Molecular Mechanisms of Cisplatin Resistance In Bladder Cancer. Expert Rev Anticancer Ther. 2012; 12(2):271-81.; doi: 10.1586/era.11.201.

34- Kim W.J., Kakehi Y., Hirai M., Arao S., Hiai H., Fukumoto M., Yoshida O. (1995). Multidrug resistanceassociated protein mediated multidrug resistance modulated by cyclosporin A in a human bladder cancer cell line. Jpn J Cancer Res, 86(10);969-77. doi: 10.1111/j.1349-7006.1995.tb03009.x.

35- Clifford S.C., Neal D.E., Lunec J. (1996). Alterations in expression of the multidrug resistance associated protein (MRP) gene in high-grade transitional cell carcinoma of the bladder. Br. J. Cancer 1996; 73(5), 659-666. https://www.nature.com/articles/bjc1996115

36- Zhu, H. B., Yang, K., Xie, Y. Q., Lin, Y. W., Mao, Q. Q., \& Xie, L. P. (2013). Silencing of mutant p53 by siRNA induces cell cycle arrest and apoptosis in human bladder cancer cells. World journal of surgical oncology, 11(1), 1-11. https://wjso.biomedcentral.com/articles/10.1186/1477-7819-11-22

37- Howl J., Mondszein R.M., Wheatley M.(1998) Characterization of G proteincoupled receptors expressed by ECV304 human endothelial cells. Endothelium, 6(1); 23-32. doi: 10.3109/10623329809053402.

38- Jung I. ve Messing E. (2000). Molecular Mechanisms and Pathways in Bladder Cancer Development and Progression; Cancer Control. 7(4):325-34. doi: 10.1177/107327480000700401.

39- Sarkis A.S., Bajorin D.F., Reuter VE, Herr H.W., Netto G., Zhang Z.F. Schultz P.K. et al,(1995). Prognostic value of p53 nuclear overexpression in patients with invasive bladder cancer treated with neoadjuvant MVAC J Clin Oncol. 13(6):1384-90. doi: 10.1200/JCO.1995.13.6.1384

40- Cote R.J., Esrig D., Groshen S., Jones P.A., Skinner D.G. (1997). p53 and treatment of bladder cancer. Nature. 385(6612):123-5. doi: 10.1038/385123b0.

\section{Acknowledgements}

The present study was supported by a grant from the Scientifc Research Projects Coordination Unit of Istanbul University (Doctorate Project no: TDK-2017-23523).

Thanks to Abdullah Yilmaz about flow cytometric analysis. Also we thanks to Assoc Prof Dr Nuray Varol for the material supplement.

Author contributions O.O.,O.E.G, K.S.,Y.I conceived and designed the present study. O.O. and O.E.G performed the experiments. O.O. and O.E.G was responsible for the data analysis and performed data interpretation. O.O.,O.E.G, K.S.,Y.I wrote the paper, revised the manuscript. A.N. is responsible for the flow cytometric analysis. H.C. is responsible for the docking analysis. 
Data availability The datasets supporting the conclusions of this article are included within the article.

\section{Declarations}

Conflict of interest The authors have declared that they have no competing interests. Ethical approval not applicable to the approval because this study was performed using cell lines. 


\section{Figures}

\section{Figure 1}

MTT assay results for calcitriol treatment in T24 (A), ECV-304 (B), HUVEC (C) cell lines with doses between $25 \mathrm{nM}$ to $1000 \mathrm{nM}$ for $24 \mathrm{~h}, 48 \mathrm{~h}$ and $72 \mathrm{~h}$. Cisplatin treatment in T24 (D), ECV-304 (E), HUVEC (F) cell lines with doses between $16.6 \mu \mathrm{M}$ to $166 \mu \mathrm{M}$ for $24 \mathrm{~h}, 48 \mathrm{~h}$ and $72 \mathrm{~h}$. Cells treated with cisplatin after 24h cell cultivation. (G); Comparison of MTT results. Control cells (non treated), $500 \mathrm{nM}$ calcitriol, 16.6 $\mu \mathrm{M}$ cisplatin and $500 \mathrm{nM}$ calcitriol $+16.6 \mu \mathrm{M}$ cisplatin for combination treatment was evaluated for $24 \mathrm{~h}$. Triplicated applications were done for all samples. Data are mean $\pm \operatorname{SEM}(n=3),(\star \star \star x<0.001, * \star p<0.01$, ${ }^{*} \mathrm{p}<0.05$, ns: non significant).

\section{Figure 2}

Annexin V/PI staining represented images for T24 (A), ECV-304 (B) and HUVEC (C) cell lines for 24h. Control cells (non treated), $500 \mathrm{nM}$ calcitriol, $16.6 \mu \mathrm{M}$ cisplatin and $500 \mathrm{nM}$ calcitriol $+16.6 \mu \mathrm{M}$ cisplatin for combination treatment was evaluated. (D) Total apoptosis results for T24, ECV-304 and HUVEC. Triplicated applications were done for all samples. Data are mean $\pm \operatorname{SEM}(n=3),\left({ }^{\star \star \star} p<0.001,{ }^{* \star} p<0.01\right.$, ${ }^{*} \mathrm{p}<0.05$, ns: non significant).

\section{Figure 3}

Represented images of P-gp exspression for T24 (A), ECV-304 (B) and HUVEC (C) cell lines for 24h. (D) Pgp results evaluation of control cells (non treated), calcitriol $(500 \mathrm{nM})$, cisplatin $(16.6 \mu \mathrm{M})$ and combination treatment (Calcitriol 500nM+ cisplatin $16.6 \mu \mathrm{M}$ ) for each three cell line. Triplicated applications were done for all samples. Data are mean \pm SEM $(n=3),\left({ }^{\star \star \star} p<0.001,{ }^{\star \star} p<0.01,{ }^{*} p<0.05, n s\right.$ : non significant).

\section{Figure 4}

Calcitriol-p53 and cisplatin-p53 interaction structures via to Docking Analysis. 